\title{
Incentive spirometry as a way to prevent pulmonary atelectasis development
}

\author{
T. S. Kuzmenko*, S. I. Vorotyntsev
}

Zaporizhzhia State Medical University, Ukraine

The purpose. The purpose of this study was to evaluate the effectiveness of incentive spirometry (IS) as a method of atelectasis prevention in patients with moderate or high risk of PPCs development after upper abdominal surgery.

Materials and methods. The study consisted of two stages. The first retrospective stage was to analyze the medical histories data of 51 inpatients, who were included in the comparison group. The prospective part of the study included 39 patients of the study group, who had sessions of the IS during the first 7 days of the postoperative period. Patients of both groups were operated on the upper abdominal organs by open procedure, operation time was more than 2 hours, all patients had an ARISCAT score $\geq 26$ points. Pulmonary atelectasis development was monitored in the groups in the first week of the postoperative period. The statistical analysis of the data was performed using the Microsoft Excel 2013 and Statistica for Windows 6.0 programs. When comparing the groups according to the clinical outcome, the relative risk (RR) and odds ratio (OR) were determined and then confidence intervals $(95 \% \mathrm{Cl})$ were calculated. Statistical significance of the results was determined depending on the $\mathrm{Cl}$ values.

Results. During the first 7 days, 34 cases of pulmonary atelectasis (67\%) were recorded in the comparison group. In the study group, 9 patients $(23 \%)$ were diagnosed with pulmonary atelectasis. The analysis of clinical results showed that when applying incentive spirometry, there was a statistically significant decrease in the relative risk of atelectasis development within the first week of the postoperative period $(R R=0.346,95 \% \mathrm{Cl}[0.189 ; 0.634], P=0.0006)$. The odds ratio of atelectasis development in the study group was statistically lower than in the group of retrospective study $(\mathrm{OR}=0.150,95 \% \mathrm{Cl}[0.058,0.386], \mathrm{P}=0.0001)$.

Conclusions. Incentive spirometry is an effective way to prevent pulmonary atelectasis in patients with a moderate or high risk for developing postoperative pulmonary complications according to the ARISCAT scale after upper abdominal surgery.

\section{Спонукальна спірометрія як спосіб запобігання розвитку ателектазів кегеневої тканини}

\section{Т. С. Кузьменко, С. І. Воротинцев}

Мета роботи - оцінити ефективність спонукальної спірометрії (CC) як способу запобігання розвитку ателектазів легень у пацієнтів із помірним або високим ризиком розвитку післяопераційних легеневих ускладнень (ПЛУ) після оперативних втручань на верхньому поверсі черевної порожнини.

Матеріали та методи. Дослідження складалося з двох етапів. Перший, ретроспективний етап, полягав в аналізі історій хвороби 51 стаціонарного хворого (група порівняння). Група дослідження - 39 пацієнтів проспективної частини дослідження, яким у перші 7 днів післяопераційного періоду проводили сеанси СС. Пацієнти обох груп прооперовані відкритим способом на органах верхнього поверху черевної порожнини тривалістю понад 2 години та мали оцінку за шкалою ARISCAT $\geq 26$ балів. У групах відстежували розвиток ателектазів легеневої тканини в перший тиждень післяопераційного періоду. Статистичне опрацювання виконали за допомогою програм Microsoft Excel 2013 та Statistica for Windows 6.0. При порівнянні груп за клінічним результатом визначали відносний ризик (ВР), відношення шансів (ВШ), для них розраховували довірчі інтервали (95 \% ДІ). Залежно від значень ДІ визначали статистичну значущість результатів.

Результати. Протягом перших 7 днів у групі порівняння зафіксували 34 випадки ателектазування легень (67 \%). У групі дослідження ателектази легеневої тканини виникли у 9 пацієнтів (23\%). Аналіз клінічних результатів показав, що при застосуванні СС відбувається статистично значуще зниження відносного ризику розвитку ателектазів у перший тиждень післяопераційного періоду (ВР = 0,346, 95 \% ДІ [0,189; 0,634], $p=0,0006)$. Відношення шансів розвитку ателектазів у групі дослідження статистично значуще нижче порівняно з групою ретроспективної частини дослідження (ВШ =0,150, 95 \% ДІ [0,058; 0,386], p= 0,0001).

Висновки. Спонукальна спірометрія є ефективним способом профілактики ателектазування легеневої тканини у пацієнтів із помірним або високим ризиком розвитку післяопераційних легеневих ускладнень за шкалою ARISCAT після оперативних втручань на верхньому поверсі черевної порожнини.

\section{Побудительная спирометрия как способ предупреждения развития ателектазов мегочной ткани}

\section{Т. С. Кузьменко, С. И. Воротынцев}

Цель работы - оценить эфрфективность побудительной спирометрии (ПС) как способа предупреждения развития ателектазов легких у пациентов с умеренным или высоким риском развития послеоперационных легочных осложнений (ПЛО) после оперативных вмешательств на верхнем этаже брюшной полости.

Материалы и методы. Исследование состояло из двух этапов. Первый, ретроспективный этап, заключался в анализе данных историй болезни 51 стационарного больного (группа сравнения). Группу исследования составили 39 пациентов проспективной части исследования, которым в первые 7 дней послеоперационного периода проводили сеансы ПС. Пациенты обеих групп прооперированы открытым способом на органах верхнего этажа брюшной полости продолжительностью

Key words: spirometry, pulmonary atelectasis, postoperative pulmonary complications.

\section{Zaporozhye} medical journal 2019; 21 (2), 199-202 DOI: 10.14739/2310-1210 2019.2.161486

*E-mail: tatianakuzmenko1212@ gmail.com

Киючові слова: спірометрія, мегень ателектази, післяопераційні мегеневі ускиалнення.

Запорізький медичний журнал. - 2019. T. 21, № 2(113). C. 199-202 
более 2 часов и имели оценку по шкале ARISCAT $\geq 26$ баллов. В исследуемых группах отслеживали развитие ателектазов легочной ткани в первую неделю послеоперационного периода. Статистическую обработку проводили с помощью программ Microsoft Excel 2013 и Statistica for Windows 6.0. При сравнении групп по клиническим результатам определяли относительный риск (ОР), отношение шансов (ОШ), для которых рассчитывали доверительные интервалы (95 \% ДИ). В зависимости от значений ДИ определяли статистическую значимость полученных результатов.

Результаты. В течение первых 7 дней в группе сравнения зафиксировали 34 случая ателектазирования легких (67%). В группе исследования ателектазы легочной ткани развились у 9 пациентов (23 \%). Анализ клинических результатов показал, что при применении СС отмечают статистически значимое снижение риска развития ателектазов в первую неделю послеоперационного периода (OP = 0,346, 95 \% ДИ $[0,189 ; 0,634], p=0,0006)$. Отношение шансов развития ателектазов в группе исследования статистически значимо ниже по сравнению с группой ретроспективной части исследования (ОШ $=0,150$, $95 \%$ ДИ $[0,058 ; 0,386], p=0,0001)$.

Выводы. Побудительная спирометрия - эффективный способ профилактики ателектазирования легочной ткани у пациентов с умеренным или высоким риском развития послеоперационных легочных осложнений по шкале ARISCAT после оперативных вмешательств на верхнем этаже брюшной полости.

The number of postoperative pulmonary complications (PPCs) in abdominal surgery ranges from 17 to $88 \%$ [1] and it leads to an increase in morbidity and mortality, length of hospital stay as well as related material costs [2,3]. Upper abdominal surgical procedures are associated with a higher risk of PPCs development [4,5].

A basic postoperative complication is a lack of lung inflation which results from a change in breathing to a shallow, monotonous pattern without periodic sighs and temporary diaphragmatic dysfunction, caused by prolonged recumbent position, and impaired mucociliary clearance, along with the decreased cough effectiveness secondary to pain that increases the risks associated with retained pulmonary secretions [6]. These factors lead to a violation of effective breathing and reduced tidal volume (TV), which in turn reduces the pulmonary compliance and depletes the surface-active substances, resulting in pulmonary atelectasis occurrence. Atelectasis is the most common pulmonary complication that can lead to the development of pneumonia in the absence of appropriate measures [7].

Chest physical therapy plays an important role in the prevention and management of postoperative pulmonary complications. It includes deep breathing exercises, mobilization, postural drainage, percussion and vibration or shaking which were developed to improve bronchial drainage as well as the employment of mechanical breathing devices such as the incentive spirometer [8]. Incentive spirometry (IS) is a lung expansion technique, which stimulates maximum inspiratory effort with the aim of the most complete filling of the alveoli with air providing a slow maximal inspiration. However, there are contradictory data on the use of IS effectiveness for PPCs prevention in patients after upper abdominal surgery [9-15].

\section{The purpose}

The purpose of this study was to evaluate the effectiveness of incentive spirometry (IS) as a method of atelectasis prevention in patients with moderate or high risk of PPCs development after upper abdominal surgery.

\section{Materials and methods}

The study consisted of two stages, namely the retrospective and prospective. Prior to the beginning of the prospective study, all patients signed an informed consent. Inclusion criteria were: age older than 18 years, risk assessment of PPCs development on the ARISCAT scale $\geq 26$, upper abdominal surgical procedures, duration of which was more than 2 hours. Exclusion criteria were: age $<18$ years, pregnancy, ASA IV-V, hemodynamic instability (cardiac index $<2.5 \mathrm{l} / \mathrm{min} / \mathrm{m}^{2}$, and $/$ or need for inotropic maintenance), intracranial lesions or brain tumors, history of mechanical ventilation in the last two weeks, history of pulmonary surgery, lung disease of any etiology, patient's refusal to participate in the study, acute respiratory failure occurrence in the first 7 days of the postoperative period. The retrospective part of the study was to analyze the medical histories data of 51 inpatients who underwent open upper abdominal surgery for abdominal pathology. The prospective part of the study included 42 patients who underwent similar surgical procedures, 3 patients were excluded from the study. Patients of the retrospective part of the study were included in the comparison group, and patients of the prospective part were assigned to the study group.

In both groups, the following indices were evaluated: demographic data, height, weight, ideal body weight (IBW), body mass index (BMI), concomitant pathology, ASA class, ARISCAT score, operative duration, duration of mechanical ventilation (MV).

In the study group, IS sessions began 2 days prior to surgery with the Coach 2 incentive spirometer (Smiths Medical International, UK) and continued immediately after being transferred to a ward on the first postoperative day. The incentive spirometer consists of two cylinders, flexible tube with a mouthpiece. A large cylinder is marked with a graduated scale in "ml" and contains a float that rises on the inspiration and shows its volume. On the large cylinder there is an indicator which can be adjusted by a clinician to mark a patient's inspiratory target. The volume of proper inspiratory capacity of the lungs (LIC) was determined by the nomogram. The scale of the smaller cylinder is graduated and displays the inspiratory flow rate. Patients inhaled at such rate when the float remained in the middle position. Exercises were performed in a sitting or semi-sitting position, the incentive spirometer was located in front of a patient. The patient inhaled deeply and slowly through a mouthpiece of the spirometer. After achieving the maximum volume the patient held this volume constant for 3-6 seconds, and then breathe out normally to the atmosphere. IS sessions were conducted for 10 minutes every 2 hours, from $10: 00$ to $20: 00$. On the first postoperative day, the initial inspiratory capacity was determined before proceeding 
with the training using the incentive spirometer. IS training lasted for a week after surgical intervention.

Pulmonary atelectasis occurrence during the first 7 days of the postoperative period was determined at the end of the study. The presence of atelectasis was revealed by a clinical sign, such as a decrease in $\mathrm{SpO}_{2} \leq 96 \%$ when breathing room air for 5 minutes as well as by ultrasound and radiological signs.

The statistical analysis of the data was performed using the Microsoft Excel 2013 and Statistica for Windows 6.0 programs. The hypothesis for the normality of quantitative indices distribution was analyzed using the Shapiro-Wilk criterion. The quantitative indices with normal distribution were represented by the mean and standard error $(\mathrm{M} \pm \mathrm{m})$ or the median and interquartile range $\left(\mathrm{Me}\left[\mathrm{Q}_{25}, \mathrm{Q}_{75}\right]\right)$, and as absolute numbers for qualitative indices not normally distributed. The Mann-Whitney's U-criterion was used as a method of nonparametric statistics to compare the quantitative data. When comparing the groups according to the clinical outcome, the relative risk (RR) and odds ratio (OR) were determined and then confidence intervals (95\% $\mathrm{Cl}$ ) were calculated. Statistical significance of the results was determined depending on the $\mathrm{Cl}$ values. If the $\mathrm{Cl}$ was in the right side of the one (all values of $\mathrm{Cl}$ greater than 1 ), then RR or the chance of pulmonary atelectasis developing in the first 7 days of the postoperative period was considered statistically significantly increased in the study group relative to the comparison group and, accordingly, conversely, left-sided Cl corresponded to lower statistical significance. If Cl for RR and OR included 1, it was considered that the differences between groups were statistically insignificant. AP value $<0.05$ was considered statistically significant.

\section{Results}

The characteristics of demographic and clinical data are presented in Table 1. There were differences between data of both groups patients in all indicators $(P>0.05)$, that confirmed our hypothesis for representativeness of the compared groups.

Patients in both groups underwent various open surgical interventions on the upper abdominal organs for abdominal pathology, which general characteristics are given in Table 2. The differences between groups are statistically insignificant.

The dynamics of LIC level in the study group in the first postoperative week is shown in Fig. 1. On the 7th day after surgery, the level of LIC was higher than the baseline by $37 \%$ and reached the appropriate level in 34 patients ( $87 \%$ ).

During the first 7 days, 34 cases of pulmonary atelectasis $(67 \%)$ were recorded in the comparison group. In the study group, 9 patients $(23 \%)$ were diagnosed with pulmonary atelectasis (Fig. 2).

The comparison of clinical results showed that when applying incentive spirometry, there was a statistically significant decrease in the relative risk of atelectasis development in the first week of the postoperative period $(\mathrm{RR}=0.346,95 \% \mathrm{Cl}[0.189 ; 0.634], \mathrm{P}=0.0006)$. $\mathrm{OR}=0.150,95 \% \mathrm{Cl}[0.058 ; 0.386], \mathrm{P}=0.0001, \mathrm{Cl}$ was to the left of 1 , indicating that the chance of atelectasis development was statistically significantly lower in the study group as compared to the retrospective part group.

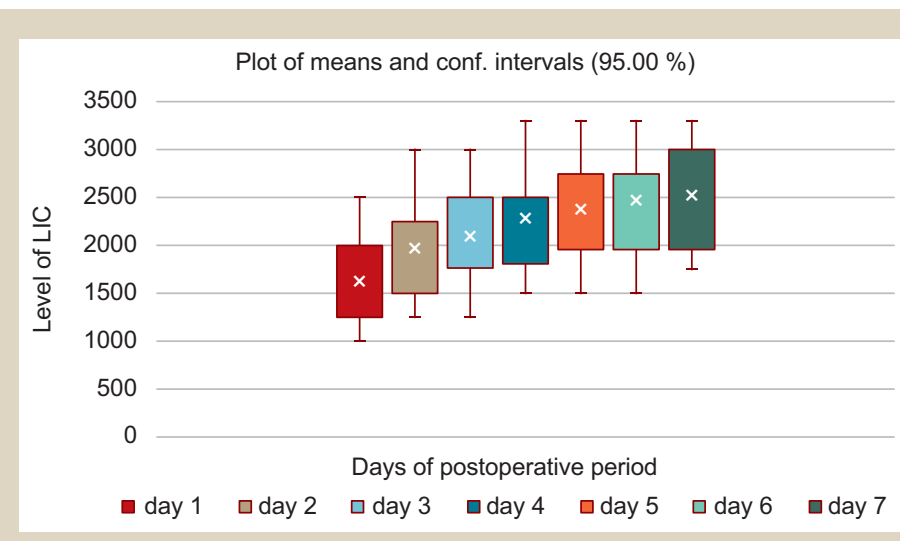

Fig. 1. Dynamics of LIC in the postoperative period.

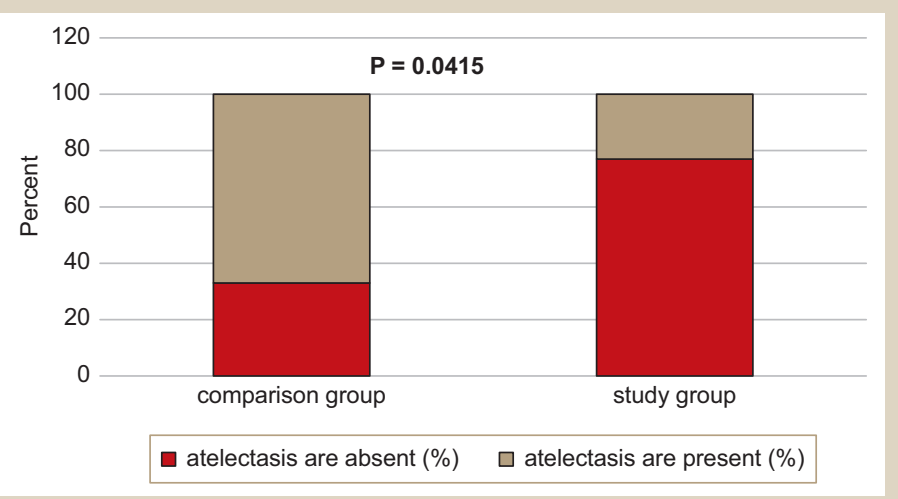

Fig. 2. Comparison of atelectasis incidence in the groups.

Table 1. Characteristics of patients, $M \pm m$ or $M e\left[Q_{25} ; Q_{75}\right]$

\begin{tabular}{|l|l|l|l|}
\hline Indicators & $\begin{array}{l}\text { Comparison Group } \\
(\mathbf{n}=51)\end{array}$ & $\begin{array}{l}\text { Study group } \\
(\mathbf{n}=39)\end{array}$ & $\mathbf{P}$ \\
\hline Age, years & $61[43 ; 69]$ & $63.9 \pm 2,36$ & 0.076 \\
\hline Sex, $\mathrm{m} / \mathrm{w}$ & $24 / 27$ & $21 / 18$ & 0.385 \\
\hline Height, $\mathrm{cm}$ & $173[165 ; 178]$ & $169.95 \pm 1.24$ & 0.333 \\
\hline Weight, kg & $77.88 \pm 2.91$ & $75.23 \pm 1.68$ & 0.952 \\
\hline IBW, kg & $66.05[57.02 ; 73.30]$ & $62.98 \pm 1.45$ & 0.582 \\
\hline BMI, kg & $26.43 \pm 0.93$ & $27.11 \pm 0.51$ & 0.128 \\
\hline ARISCAT, score & $40.13 \pm 1.11$ & $40.38 \pm 2.38$ & 0.088 \\
\hline ASA I/II/III, $\mathrm{n}$ & $8 / 21 / 22$ & $3 / 18 / 18$ & 0.345 \\
\hline Duration of operation, $\min$ & $144.61 \pm 5.96$ & $128.46 \pm 6.71$ & 0.061 \\
\hline Duration of MV, min & $37578 \pm 90.66$ & $302.69 \pm 78.37$ & 0.058 \\
\hline
\end{tabular}

Table 2. Characteristics of surgical interventions, $n(\%)$

\begin{tabular}{l|l|l|}
\hline Types of surgical interventions & $\begin{array}{l}\text { Comparison group } \\
(\mathbf{n}=\mathbf{5 1})\end{array}$ & $\begin{array}{l}\text { Study group } \\
\mathbf{( n = 3 9 )}\end{array}$ \\
\hline Operative intervention on the liver and bile ducts & $19(37 \%)$ & $14(36 \%)$ \\
\hline Operative intervention on the stomach and duodenum & $21(41 \%)$ & $15(38 \%)$ \\
\hline Operative intervention on the small intestine & $11(22 \%)$ & $10(27 \%)$ \\
\hline
\end{tabular}

\section{Discussion}

In our work, the effectiveness of incentive spirometry as a way of pulmonary atelectasis prevention has been proved. These data coincide with the results of Berman et al. (2012) [9], which show that breathing exercises aimed at maximizing the inhalation efforts during IS are most useful for the prevention of respiratory complications such as 
atelectasis and pneumonia. Westwood et al. (2007) [10] found a decrease in respiratory complications after major abdominal surgery in patients using incentive spirometers and confirmed that the IS helps reduce the length of stay in a hospital. They also acknowledged that maximizing inhalation efforts during IS plays an important role in preventing atelectasis and their complications. In Pelus and Kaplan's study (2006) [11], it was emphasized that IS is an effective strategy to reduce the risk of pulmonary complications for patients after open surgical interventions in abdominal surgery. In addition, incentive spirometers are easy to use and there is the possibility of using it independently after the previous training as well as a visual feedback that allows a patient to record obtained LIC indicators yourself. However, there is another opinion on the effectiveness of the IS, as Pantel H. et al. (2017) [12] did not reveal any influence of the IS on the postoperative pulmonary complications development in patients after bariatric surgery, therefore its use is not recommended for this category of patients. Paulo do Nascimento Junior et al. (2014) [13] reviewed the data from 12 studies published before August 2013 and concluded that there was low quality evidence regarding the lack of effectiveness of incentive spirometry for prevention of postoperative pulmonary complications in patients after upper abdominal surgery. This review emphasized the urgent need to conduct well-designed trials in this field.

\section{Conclusions}

Incentive spirometry is an effective way to prevent pulmonary atelectasis in patients with a moderate or high risk for developing postoperative pulmonary complications according to the ARISCAT scale after upper abdominal surgery.

Prospects for further research. Patients with a moderate and high risk of PPCs development require particular attention; therefore it is necessary to develop a complex perioperative respiratory support for this category of patients taking into account specific features of pulmonary tissue mechanical properties of each patient. This direction is promising in modern respiratory medicine and needs further research.

Conflicts of interest: authors have no conflict of interest to declare. Конфмікт інтересів: віАсутній.

Надійшла Ао редакції / Received: 29.06.2018

Після Аоопрацювання / Revised: 11.07.2018

Прийнято АО Аруку / Accepted: 20.07.2018

Information about authors:

Kuzmenko T. S., MD, Postgraduate Student, Department of Surgery and Anesthesiology of Postgraduate Education Faculty, Zaporizhzhia State Medical University, Ukraine.

Vorotyntsev S. I., MD, PhD, Associate Professor, Department

of Surgery and Anesthesiology of Postgraduate Education Faculty, Zaporizhzhia State Medical University, Ukraine.

\section{Відомості про авторів:}

Кузьменко Т. С., аспірант каф. хірургії та анестезіології ФПо, Запорізький державний медичний університет, Україна. Воротинцев С. І., канА. меА. наук, Аоцент каф. хірургії та анестезіології ФПО, Запорізький державний медичний університет, Україна.
Сведения об авторах:

Кузьменко Т. С., аспирант каф. хирургии и анестезиологии ФПо, Запорожский государственный меАицинский университет, украина.

Воротынцев С. И., канА. меА. наук, Аоцент каф. хирургии и анестезиологии ФПО, Запорожский государственный медицинский университет, Украина.

\section{References}

[1] Guimarães, M., El Dib, R., Smith, A. Matos, D. \& Gomes, B. (2009). Incentive Spirometry for Prevention of Postoperative Pulmonary Complications in Upper Abdominal Surgery. Anesthesia \& Analgesia 109(5), 1700

[2] Souza Possa, S. Braga Amador, C. Meira Costa, A. , Takahama Sakamoto, E., Seiko Kondo, C. , Maida Vasconcellos, A. , et al. (2014). Implementation of a guideline for physical therapy in the postoperative period of upper abdominal surgery reduces the incidence of atelectasis and length of hospital stay. Revista Portuguesa de Pneumologia (English Edition), 20(2), 69-77. doi: 10.1016/j.rppneu.2013.07.005

[3] Pileggi, C. Bianco, A., Flotta, D. Nobile, C. \& Pavia, M. (2011) Prevention of ventilator-associated pneumonia, mortality and all intensive care unit acquired infections by topically applied antimicrobial or antiseptic agents: a meta-analysis of randomized controlled trials in intensive care units. Critical Care, 15(3), R155. doi: 10.1186/cc10285.

[4] Restrepo, R., Wettstein, R. , Wittnebel, L. , \& Tracy, M. (2011). Incentive Spirometry: 2011. Respiratory Care, 56(10), 1600-1604. doi: 10.4187/ respcare. 01471

[5] Arruda, K. , Cataneo, D. , \& Cataneo, A. (2013). Surgical risk tests related to cardiopulmonary postoperative complications: comparison between upper abdominal and thoracic surgery. Acta Cirurgica Brasileira, 28(6), 458-466. doi: 10.1590/\$0102-86502013000600010

[6] Grams, S., Ono, L., Noronha, M. , Schivinski, C. , \& Paulin, E. (2012). Breathing exercises in upper abdominal surgery: a systematic review and meta-analysis. Brazilian Journal of Physical Therapy, 16(5), 345-353. doi: 10.1590/S1413-35552012005000052

[7] Kulaylat, M. N., \& Dayton, M. T. (2012): Surgical complications. In: Townsend Jr CM et al. Sabiston Textbook of Surgery: The Biological Basis of Modern Surgical Practice. Philadelphia, PA: Saunders Elsevier.

[8] Pasquina, P., Tramér, M., Granier, J. , \& Walder, B. (2006). Respiratory Physiotherapy To Prevent Pulmonary Complications After Abdominal Surgery. Chest, 130(6), 1887-1899. doi: 10.1378/chest.130.6.1887

[9] Berman, A. , et al. (2012) Kozier \& Erb's Fundamentals of Nursing: Concepts, Process, and Practice. Boston, MA: Pearson Education, Inc

[10] Westwood, K. , Griffin, M. , Roberts, K. , Williams, M. , Yoong, K. , \& Digger, T. (2007). Incentive spirometry decreases respiratory complications following major abdominal surgery. The Surgeon, 5(6), 339-342. doi: 10.1016/S1479-666X(07)80086-2

[11] Pelus, S. , \& Kaplan, D. (2006) What the new guidelines offer for pre-operative risk reduction. Patient Care, 40(10), 18-25.

[12] Pantel, H. , Hwang, J. , Brams, D. , Schnelldorfer, T. , \& Nepomnayshy, D. (2017). Effect of Incentive Spirometry on Postoperative Hypoxemia and Pulmonary Complications After Bariatric Surgery. JAMA Surgery, 152(5), 422. doi: 10.1001/jamasurg.2016.4981

[13] do Nascimento Junior, P. , Módolo, N., Andrade, S. , Guimarães M., Braz, L. , \& El Dib, R. (2014). Incentive spirometry for prevention of postoperative pulmonary complications in upper abdominal surgery. Cochrane Database of Systematic Reviews, 2, CD006058. doi: 10.1002/14651858.CD006058.pub3

[14] Rupp, M. Miley, H. \& Russell-Babin, K. (2013). Incentive Spirometry in Postoperative Abdominal/Thoracic Surgery Patients. AACN Advanced Critical Care, 24(3), 255-263. doi: 10.1097/NCl.0b013e31828c8878

[15] Alaparthi, G. , Augustine, A. , Anand, R. \& Mahale, A. (2016) Comparison of Diaphragmatic Breathing Exercise, Volume and Flow Incentive Spirometry, on Diaphragm Excursion and Pulmonary Function in Patients Undergoing Laparoscopic Surgery: A Randomized Controlled Trial. Minimally Invasive Surgery, 2016, 1967532. doi: 10.1155/2016/1967532 